\section{MARINE ECOLOGY AND THE FISHERIES}

$\mathrm{W}$ ITH the present two numbers of the Hull Bulletins of Marine Ecology, volume 1 is complete*. Of volume 2 four numbers are already published and three are in the press. Prof. A. C. Hardy, editor of these bulletins, in his explanation at the beginning of volume 1 gives an excellent simplified résumé of the whole. Ecology as he defines it "is establishing the relationship between a creature and its surroundings in terms of quantity". He sketches the gradual growth of marine ecology with admirable clarity, its scope, early history, and the beginning of the work at Hull leading to all these researches. This work, planned by himself and successfully carried out, includes his invention of the plankton indicator and, following this, the plankton recorder, both of which have proved to be of real help to the fishery industry. Here a story is told in the simplest terms which is of special interest and importance. It has always been Prof. Hardy's aim to bring science and industry together. How successful he has been is shown in the tributes paid to him by the skippers of the vessels which have his apparatus in use.

His explanation proceeds to summarize each bulletin in volume 1. Again as simply as possible the contents of each part are explained, with clear diagrammatic illustrations of apparatus and of planktonic organisms. This is an excellent method of introducing the work to non-specialists.

No. 6, concerned with the main plankton survey, deals with the monthly changes in the zooplankton other than Copepoda and young fish as shown by the plankton recorder. Here the seasonal changes are much in evidence, and the distribution of Sagitta, Limacina, Clione, Lamellibranch larvæ, Cladocera, Caprellid Amphipoda, Decapod larvæ, Echinoderm larvæ and Oikopleura is shown in series of monthly charts, while the seasonal fluctuations are compared in time-chart histograms.

These researches have been suspended for the present; but it is hoped that they may be developed in several directions for a long period in the future.

* Hull Bulletins of Marine Ecology, edited by Prof. A. C. Hardy and Dr. C. E. Lucas. Vol. 1, pp. i-xlifi, October 1944, 3s. Title Page, Contents Table, List of Personnel, Preface and Explanation. Vol. 1, Plankton Records. The Zooplankton (other than Copepoda and Young Fish) in the Southern North Sea, 1932-37, by Dr. G. T. D. Henderson and N. B. Marshall.

\section{THEOLOGY IN AN AGE OF SCIENCE}

$I^{\mathrm{N}}$

his inaugural lecture at the University of Oxford 1 on November 3, 1944 (Oxford: At the Clarendon Press, 2s. net), Prof. Leonard Hodgson, regius professor of divinity, asked how the voice of theology is to be heard in a scientifically minded age. Must it not inevitably belong to a world of thought alien to the scientific outlook ?

Science has been defined by Dr. C. H. Waddington as "the organized attempt to discover how things work as causal systems". This view assumes that all events are explicable in terms of causal systems (or that there are no events lying outside the range of scientific study). In this case, does the fact that psychologists and sociologists are recognized as men of science mean that all human behaviour can be accounted for on causal grounds ? Or that they can study only such aspects of it as are thus causally explicable?

To take the former view is to beg a very large question; to take the latter is to assert that there can be no scientific study of such purposive behaviour as is explicable in terms not of causes but of reasons -a limitation which psychologists and sociologists would reject.

The fact is, remarks Prof. Hodgson, "we live in a world in which there are two orders of events-those which follow from causes, and those which are done on purpose, for reasons". Thus, if science limits itself strictly to the causal order it can only deal with one part of our experience.

If theology is a science, it would presumably deal with a subject-matter not dissimilar to those of psychology and sociology, that is, events which are done on purpose, for reasons.

Rejecting the traditional idea of revelation as "erroneous and untenable", Prof. Hodgson declares that "the divine revelation is not given in the form of propositions conveying a ready-made knowledge, but in events which are divine redemptive acts". These acts, and the evidence for them, it is the business of theology to study, and here lies its claim to be a science.

"Theology is itself one of the sciences-the empirical study of the evidence for certain mighty acts of God in the history of the world."

To be scientific, such studies would have to be wholly unprejudiced. Of course the evidence for some of these events, and these not the least important, is not easy to establish : and it is perhaps not justifiable to speak of these events, as Prof. Hodgson does, as "a certain sequence of events which, as events, are as observable as any others".

Theology then would appear to be a science in the same sense as history is one. But to divest theology of its philosophical aspects would be to divest it of most of its interest and depth.

\section{RESOLUTION OF EXTRAGALACTIC NEBULAE}

$\mathrm{U}$ NLIKE the other nebulæ in the local group, the two companions of the Andromeda nebula$M 32$ and NGC 205 and the central region of the Andromeda nebula itself, have hitherto defied resolution into stars by the most powerful instruments at the disposal of astronomers. It was therefore supposed that the luminosity of their brightest stars was abnormally low. This conclusion is amply confirmed by the resolution of these objects on plates taken recently on the 100-in. telescope (W. Baade, Astrophys. J., 100, 137 ; 1944).

Some time ago, unexpected signs of incipient resolution on ordinary plates taken under good conditions gave grounds for hoping that further refinements of technique would lead to complete resolution. This has now been achieved by the use of red-sensitive plates behind a filter passing only the region 6300-6700 A., so as to avoid the strong night-sky emission. Only nights of exceptional definition were used, and only these if the temperature variations were such as to minimize changes of form of the 100-in. mirror. The plates were obtained with exposures of the order of four hours, and show that 
the hitherto amorphous structure of these galaxies has disintograted into a great number of faint red stars close to the threshold limit of the plates.

This behaviour is quite unlike that of the hitherto resolvable systems, in which the brightest stars are white and are relatively rare. Baade believes that the galaxies contain two types of stollar population. differing in their Hertzsprung-Russell diagrams. Type I contains $O$ and $B$ supergiants and open clusters, and is exemplified by the slow-moving stars in the solar neighbourhood; type II, exhibited pure only in early-type nebulæ,. contains short-period Cepheids and globular clusters. Both types co-exist in our own galaxy.

This new technique for resolving extragalactic nebulæ by employing red-sensitive plates in the best observing conditions with the 100 -in. telescope has also shown that even early-type nebulæ can be resolved if their distance does not exceed 300 kiloparsecs. Since this is the distance usually taken to mark the boundary of the 'local group' of galaxies, the criterion of resolvability becomes the test of membership of the local group. This test, applied by Baade (Astrophys. J., 100, 147; 1944) to NGC 147 and to $N G C$ 185, shows that these inconspicuous companions of the Andromeda nebula are local galaxies best elassified as elliptical nebulæ of low luminosity and small density gradient. These additions increase the number of recognized members of the local group from eleven to thirteen, and dwarf galaxies now outnumber giants by two to one.

The proportion of elliptical systems is steadily rising as a result of recent discoveries: they now number nearly a half of the known local nebulæ. The now data do not support the view that globular clusters and elliptical nebule lie at opposite ends of a common sequence of stellar agglomerations. The biggest globular clusters are still some ten times smaller in linear dimensions than the smallest elliptical nebulæ, and the mean densities of the two systems differ by a factor of the order of fifty.

\section{FORTHCOMING EVENTS}

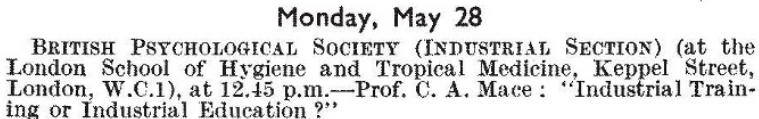

\section{Tuesday, May 29}

ROYal COLLege of Surgeons (Lincoln's Iun Fields, London, w.C.2), at 4 p.m.-Prof. Arnold Sorsby: "Penicillin and Gramicidin $\mathrm{S}$. in Ophthalmology". EUGENICS SocIETx (at Royal Society, Burlington House, London,
W.1), at 5 p.m.--Mr. Cyril Bibby: "Sex Education-Aims, Possibilities and Plans".

TELevision Socrexy (at the Institution of Electrical Engineers, Savoy Place, Victoria Embankment, London, W.C.2), at 6 p.m.Wednesday, May 30

ROYAL SOCIETY of ARTs (at John Adam Street, Adelphi, London, W.C.2), at 1.45 p.m.-Dr. Colin. G. Butler: "The Behaviour of Bees when Foraging".

SOCIETT OF CHEMICAL INDUSTRY (Plastics GROtP) (at the Roya Institution, Albemarle Street, London, W.1), at 3 p.m.-Mr. H. V.
Potter: "Leo Hendrik Baekeland: The Story of His Life" (first Batter: "Leo Hendrik Baekeland Memorial Lecture).

PHYSICAx SocieTy (Colour Group) (at the Royal Photographic Society, 16 Prince's Gate, London, S.W.7), at 3.30 p.m.-Mr. L. C. Jesty : "Colour Telerision".

\section{Thursday, May 31}

INSTITUTE OF FuEL (at the Institution of Mechanical Engineers Storey's Gate, St. James's Park, London, \$.W.1), at 10.30 a.m. and 2.30 p.m.-Conference on "Industrial
opened by Dr. E. W. Smith, C.B.E.).
Royal Aeronautical Society (at the Institution of Mechanical Engineers, Storey's Gate, St. James's Park, London, S.W.1), at (Thirty-third Wilbur Wright Memorial Lecture).

Friday, June 1

RoYal INSTITUTION (at 21 Albemarle Street, London, W.1), at 5 p.m.-Prof. James Gray, F.R.S.: "Migration of Animals".

Institution of MEChanicat ENgineers (at Storey's Gate, St. James's Park, London, S.W.1), at 5.30 p.m.-Exhibition of Films of Engineering Interest.

Grologrsts' Assocration (at the Geological Society of London, Burlington House, Piccadilly, London, W.1), at 6 p.m. - Prof., A. Austin Miller: "Some Physical Features of the Dolgelly District"."

\section{APPOINTMENTS VACANT}

APpLIOATIONS are invited for the following appointments on or before the dates mentioned:

LECTURER IN ORGANIC CHEMISTRY at the City of Liverpool Tech nical College-The Director of Education, 14 ' Sir Thomas Street, Liverpool 1 (June 1).

LECTURER IN PHYSICS at Loughborough College, LeicestershireThe Registrar (June 7)

TUtoR, and Assistant TUTOR, in The Departuent of Sochat Scrence, London School of Eeonomics and Political Science-Acting Secretary, at the Hostel, Peterhouse, Cambridge (June 8).

LFCTURER IN RUBBER TECHNOLOGY at the Northern Polytechnic, Holloway Road, London, N.17-The Clerk (June 13).

DIRRCTOR OF RESEARCH at the Institution of Automobile Engineers - Research Department of the Institution, Great West Road, Brentford, Middlesex, marked "Director of Research" (June 16).

AssistanT Likoturer in ANATOMY, London (Royal Free Hospital) School of Medicine for Women, Hunter Street, Brunswick Square, London, W.C.1 - The Wirden and Secretary (June 23).

Profrssor of PHYSIOLOGY at King's College of Household and Social Science-The Academic Registrar, University of London, Richmond College, Richmond, Surrey (June 26).

METAnLURGIST in Midlands for research work on cemented carbides METALLURGIST in Midlands for research work on cemented carbides
-The Ministry of Labour and National Service, Central (T. and S.) Register, Room 5/17, Sardinia Street, London, W.C.2 (quoting Register, Room 5/17,
F.4005.XA) (June 30).

READER (June 30). King's College, Newcastle-upon-Tyne-The Registrar of King's College (June 30 )

Profassor of INDUstrial Health in the University of Durham, tenable at the Medical School, King's College, Newcastle-upon-TyneThe Registrar of King's College (July 31).

FELLowshrp in Economas at Baliol College, Oxford-w-The Master's Secretary (Aug. 31).

VICE-PRINCIPAL (woman) of Wye College (University of London) with experience in university teaching in science, horticulture, agriculture or economics-The Acting Principal, Wye College, near Ashford, Kent.

\section{REPORTS and other PUBLICATIONS}

\section{(not included in the monthly Books Supplement)}

\section{Great Britain and Ireland}

Imperial Bureau of Animal Health. Review Series, No. 2: Modes of Spread of Streptococeus Agalactiae Infection in Dairy Herds. A Report on Co-ordinated Observations Organised by the Agrieultural Research Council of the United Kingdom. Pp. iii +28. (New Haw, Weybridge: Imperial Bureau of Animal Health, 1944.) 38 . [284 Institution of Electrical Engineers. Report of the Council for the Year 1944-1945. Pp. 12. (London : Institution of Electrical Engineers, 1945.)

Carnegie United Kingdom Trust. Thirty-first Annual Report for the Year 1944. Pp. 8. (Dunfermline : Carnegie United Kingdom

Trust, 1945.)
John Innes Horticultural Institution. Thirty-fifth Annual Report John Innes Horticultural Institution. Thirty-fifth Annual Report Pp. $60+8$ plates. 28 . 6 . (London: John Innes Horticultural Institution, 1945.)

\section{Other Countries}

Transactions of the San Diego Society of Natural History. Vol. 10, No. 10: A New Race of Kangaroo Rat from the Argus Mountains, California. By Laurence M. Huey. Pp. 131-132. Vol. 10, No. 11: The Geckos of the Genus Coleonyx with Descriptions of New Subspecies. By Laurence M. Klauber. Pp. 133 216. (San Diego, Calif.: San Diego Society of Natural History, 1945.) [214 Zoological Society of San Diego. Publication No. 21: Herpetological Correlations; 1 . Correlations in Homogeneous Populations. By Laurence M. Klauber. Pp. 101. (San Diego, Calif. : Zoological Society of San Diego, 1945.)

Transactions of the Mining Geological and Metallurgical Institute Transactions of the Mining, Geological and Metallurgical Institute of India. Vol. 39, No. 4: A Contribution to the Study of Ordinary Carbon and Medium Manganese Steel Rails. By J. S. Vatchegandhy and Dr. G. P. Contractor. Pp. vi $+200+14$ plates. Vol. 40, No. 1 : The Course of Recent and Future Developments in the Steel Trade in India. By R. A. Macgregor. Pp. 24. (Calcutta : Mining, Geologica and Metallurgical Institute of India, 1944.) [284 Indian Research Fund Association. Special Report No. 12: Studies on Basal Metabolism in India. By Dr. V. N. Patwardhan. Pp. 22.
(Cawnpore: Job Press, 1944.) 6 annas. 